\title{
Case 1: The European Capital of Culture
}

\section{From the Policy Discourse to the Implementation and Reception}

The European Capital of Culture (ECOC) is the longest running EU cultural initiative with a strong emphasis on foregrounding common culture in Europe, promoting European cultural narratives, supporting the cooperation of European cultural actors, and activating Europeans to participate in cultural creation and reception. This action forms our first case study. As discussed in Chapter 3, the macro-level policy discourse of the action seeks to construct Europe as a cultural entity and thus advance cultural Europeanization. The EU's interest in strengthening the discourse of the 'European dimension' in the ECOC action responds to the European Commission's view that this dimension was lacking in both ECOC applications and the cultural programmes of designated cities. This view was based on various ex-post evaluations of the action that noted how the European dimension has often been only modestly dealt with in the ECOC applications and cultural programmes (see Chapter 3). Indeed, the European dimension may be challenging to measure and therefore to perceive in the ECOC applications and programmes because Europe and the 'European' can be understood and manifested in various ways.

In this chapter, we first briefly outline how the 'European' was discussed and framed in the applications, commonly referred to as bid books, of three case ECOCs - Pécs2o10 in Hungary, Tallinn2o11 in Estonia, and Turkuzo11 in Finland - and how the European Commission's ex-post evaluations of them considered their European dimension. After this, these macro- and meso-level discussions are broadened by discussing field research observations from these cities. The observations offer first-hand information about how the 'European' was manifested in ECOC events themselves, in their marketing and information signs in the cities, and in diverse cultural regeneration practices in their urban space. We then analyze the results of a questionnaire study conducted with audiences in these Ecocs, focusing on how the respondents understood the 'European' in the context of the ECOC events. We conclude that for the three cities, the European dimension was indeed included in their ECOC bid books, the implementation of their ECOC year, and their audiences' perception of the events organized during it. While their understandings of the 'European' vary greatly in both form and content, some elements of understanding the 'European' recur in our data. 
In 2006 Pécs, a city in Southern Hungary with 157,00o inhabitants, was designated as the ECOC for 2010 along with two other cities: Essen, including the broader Ruhr region, in Germany, and Istanbul in Turkey. Tallinn, the capital of Estonia with a population of 426 ,ooo, and Turku, a city with 180,00o inhabitants located in South-West Finland, were selected in 2007 as the Ecocs for 2011. The three cities differ in terms of their social, cultural, economic, and political history. Their host countries - Hungary, Estonia, and Finland - are geographically located in the eastern and northern borders of the EU (Pécs is even located at the EU's southern border) and have joined the Union in different phases - Finland in 1995 and Hungary and Estonia in 2004. Two of the cities, Tallinn and Pécs, are in former socialist countries. The three cities have several characteristics in common. In all of them, contemporary art and culture have been developed together with old urban layers through public art, artistic events, new museums and other cultural institutions, and new or renewed architecture. All three cities have been multicultural and multilingual players of their regions since the Middle Ages. These similarities and differences can be perceived from the cities' ECOC bid books and programmes.

\section{Manifestations of the 'European' in the Official Discourse of Pécs2010, Tallinn2o11, and Turku2o11}

People living along borders enjoy an experience of Europe which is very different from that seen by people living in the Western European centre. (Takáts 2005, 22)

As a candidate for the European Capital of Culture 2011, Tallinn and Estonia have the potential to return to the European Cultural map as full members, forming a new European identity. (Tarand 2006, 26)

Through encounter, interaction and internationality, our children become open-minded European citizens who reinforce the European multicultural community. (Helander et al. 2006, 9)

These three quotations from the ECOC bid books of Pécs, Tallinn, and Turku indicate different ways of dealing with the 'European' in the framework of this EU action. The quotations reflect the different historical and societal contexts of the cities, which impact on how the 'European' was approached and utilized in their ECOC programmes. At the same time, these quotations indicate a common interest in being or becoming European. 
The ECOC programmes in the three case cities followed the same EU policy guidelines. Thus, the programmes had several similar emphases, aims, and interests. During their ECOC year, the cities aimed to promote the cultural characteristics of the city, its surrounding region, host country, and Europe. The main themes of Pécs2o1o followed the slogan 'Pécs - The Borderless City'. The city's bid book named several pillars of its ECOC year: lively public spaces, cultural heritage and innovation, multiculturalism, regionalism, and the city as a cultural gateway to the Balkans (Takáts 2005, 17). Europe and a common European cultural identity were important concepts in the promotional rhetoric of Pécs2o10. The objectives of the city included celebrating "artistic achievements of European standard" (Takáts 2005, 11), "diversity of European and world culture" (Toller 2005, 7), and invoking in visitors "aspects of culture which contribute to the heritage of Pan-European culture" (Takáts $2005,21)$.

In the ex-post evaluation for the EU, the Pécs cultural programme was considered as strongly emphasizing its European dimension, through "the common cultural heritage and historical links between the city and neighboring countries in southeast Europe" (Ecorys 2011b, 86). Moreover, the evaluation report noted that the 'European' was manifested in Pécs2o10 through activities whose content, delivery mechanism, and audiences were "European in essence" (Ecorys 2011b, 91). Content-wise, "the European theme promoted by Pécs focused on its potential as a 'Gateway to the Balkans', with many cultural activities focused on promoting a pan-Balkan culture" (Ecorys 2011b, 91). As delivery mechanisms, the report emphasized cooperation with cities in neighboring countries and noted that the city experienced a very substantial increase in European visitors (Ecorys 2011b, 92).

The main objectives of Tallinn's ECOC year were developing cultural participation, a creative economy, international cultural communication, and cultural tourism (Tarand 2006). Tallinn's bid book also emphasized the importance of introducing local culture to people beyond Estonia. The book stated: "Although home to many cultures, Tallinn firmly represents the character of the Estonian people and their land", and, thus, "it bares the responsibility of representing the republic and its culture to the world" (Tarand 2006, 11). The national emphasis was, however, intertwined with creating and strengthening European identity. The bid book stated: "Tallinn's leaders envisage the cultural capital as one part of a far-reaching process of transforming urban spaces into cultural centers and introducing Estonian culture to the rest of Europe while helping Estonians create a new European identity" (Tarand 2006, 17). The aim was to familiarize other Europeans with the Estonian culture and transform the notions of Europe among Estonians. This kind of two-way Europeanization 
has characterized other Estonian attempts to opening up the country to Europe and 'becoming' more European (see Kaasik-Krogerus 2019).

In both the selection documents and the ex-post evaluation, Tallinn received criticism for lacking a strong European dimension and focusing too much on celebrating local and national culture (on similar criticism in the EHL context, see Lähdesmäki et al. 2020). Due to the criticism from the selection panel, Tallinn changed the focus of its programme from folklore and fairytales to opening up the city to the sea. Still, the new focus was considered in the ex-post evaluation report as being "of local rather than European significance" (Ecorys 2012, 27). According to the report, which evaluated Tallinn2o11 and Turku2o11 simultaneously, in both cities the European dimension mostly related to efforts to support transnational cultural cooperation and to internationalize the cities' cultural sectors (Ecorys 2012, 65).

In Turku's bid book, the main goals for the ECOC year were to encourage well-being, internationalism, creative industries, and cultural export (Helander et al. 2006). The programme of Turkuzo11 was organized under five main themes: bringing culture into everyday life, offering cultural breaks from everyday life, introducing the maritime region surrounding the city, discussing issues related to identities and selfhood, and exploring the city through its history, memories, and stories (Määttänen 2010, 7). Besides the everyday, local, and regional aspects, Turku2o11 sought to include the European dimension in its ECOC year. In the bid book, the European dimension was simply defined as a value penetrating each project in the city's ECOC programme (Helander et al. 2006, 37).

The panel monitoring its preparations recommended that Turku foreground the European dimension better (Ecorys 2012, 39). The ex-post evaluation of Turku's ECOC year recognized that the European dimension manifested for instance through "attracting cultural productions from other European countries", "highlighting environmental issues especially related to the Baltic Sea", and "developing two opera productions based on ancient and medieval history in Europe" (Ecorys 2012, viii). The evaluators came to the conclusion that Turkuzon "attempted to emphasize a local 'narrative' and yet articulate it in European context and to European audiences" (Ecorys 2012, 46-47) but European themes did not permeate the entire cultural programme (Ecorys 2012, 65).

To sum up, the European dimension was dealt with in the official discourse of all three case ECOCs, but only Pécs2o10 managed to discuss and concretize it in a way that the external evaluators considered as sufficiently European. 
Even though the ex-post evaluators thanked one city and criticized two of them for their approach to the European dimension, none of the cities can be reproached for lacking, ignoring, or misinterpreting it. The 'European' includes diverse interpretations and understandings of its contents, meanings, and contexts, and can be, thus, dealt with in various ways. The ethnographic research focusing on the micro level helps to understand how the European dimension was perceived and how, thus, the 'European' could be faced by ECOC audiences in the cities. One of the authors of this book explored how the European dimension was manifested and delivered to the audiences in the three cities through an observation during fieldwork in Pécs in April, May, and October in 2010, in Tallinn in May 2011, and in Turku in August 2011. The observation included participation in dozens of cultural events, gaining first-hand experiences of their contents, arrangement, and promotion practices. In addition, diverse regeneration, reparation, restoration, and construction projects were observed, considering their impacts on urban space and people's everyday lives. The observation was documented by taking notes and by photographing the transformation of public spaces and the cultural participation of the audiences in the ECOC events.

The ECOC title means a major endeavor for the host cities that both visitors to and inhabitants of the city cannot help noting. Celebration of the cultural year is linked in the Ecocs to the ideas of Europe and the EU through various discursive, visual, material, and spatial means. The most obvious means to manifest these is widespread use of the Ecoc logos and slogans, combined with the EU flag, in promotional and information material and on signs and banners in the cities. This marks both urban space and various cultural events organized in it as 'European'. In addition, the signs and banners in the city connect efficiently the 'local', and the very spots where they are located, to the idea of Europe - 'Europe is here' in this city, in this park or building, and at this venue or work of art (see Figure 4.1 and 4.2).

In the brochures, leaflets, and other printed and online promotional material, ECOC events are typically described as European when they include performers, artists, and works of art from other European countries. This European character of the events was also often emphasized in their opening speeches or welcoming words in the three case Ecocs. Particularly in bigger festival-type events, this kind of European dimension, stemming from art 'imported from elsewhere in Europe', was easy to experience. During various festivals in the 


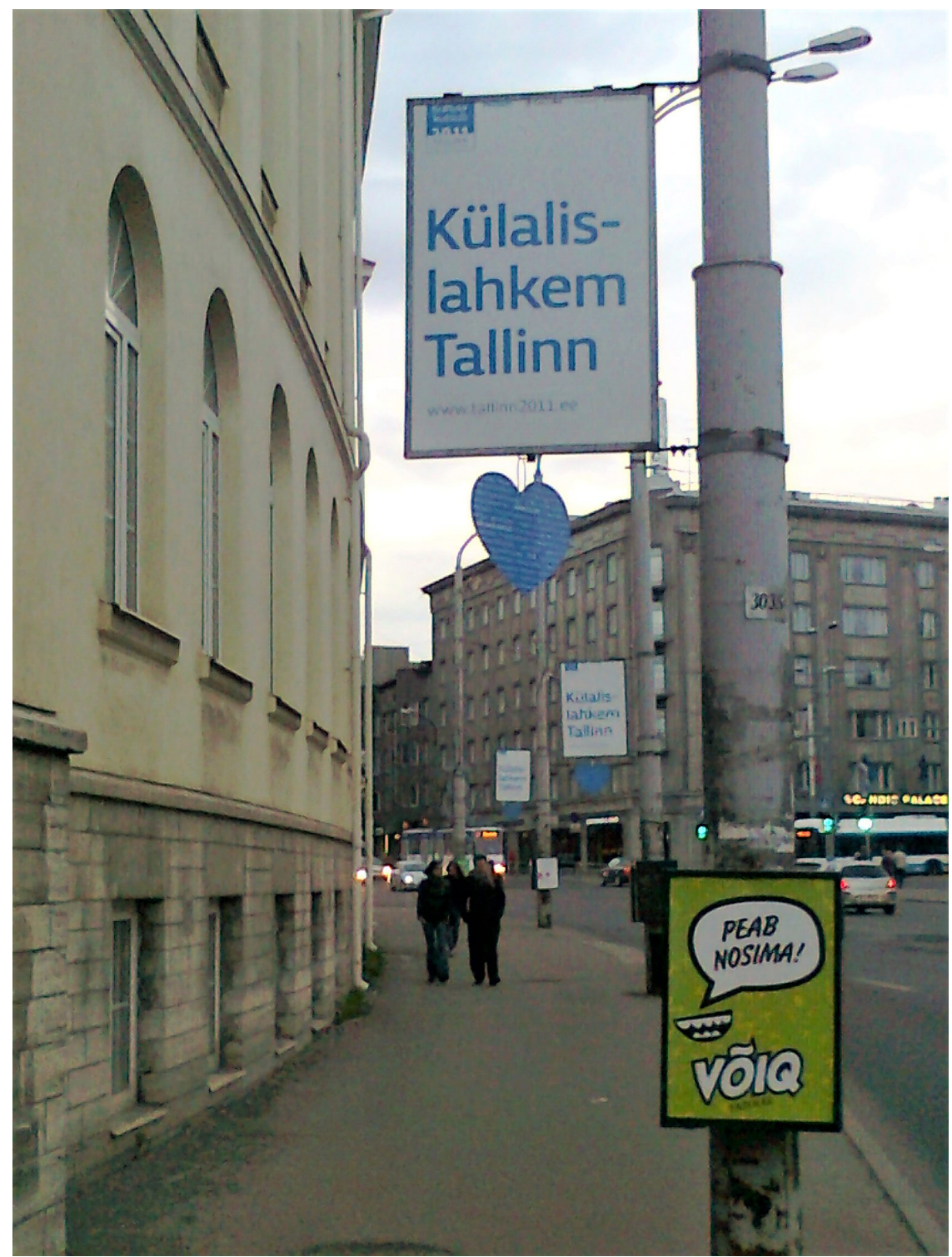

FIGURE 4.1 Sign boards with the ECOC title in a Tallinn street scene in 2011. The text on the board says 'More hospitable Tallinn'.

PHOTO: TUULI LÄHDESMÄKI

case ECOCs, the city centers were enlivened by foreign performers, performing groups, and audiences from different countries. The multinational nature of these events could be experienced through the multiplicity of languages used in the performances, heard among the audiences, and printed in the communication materials. The use of national flags in the events or the texts in the 


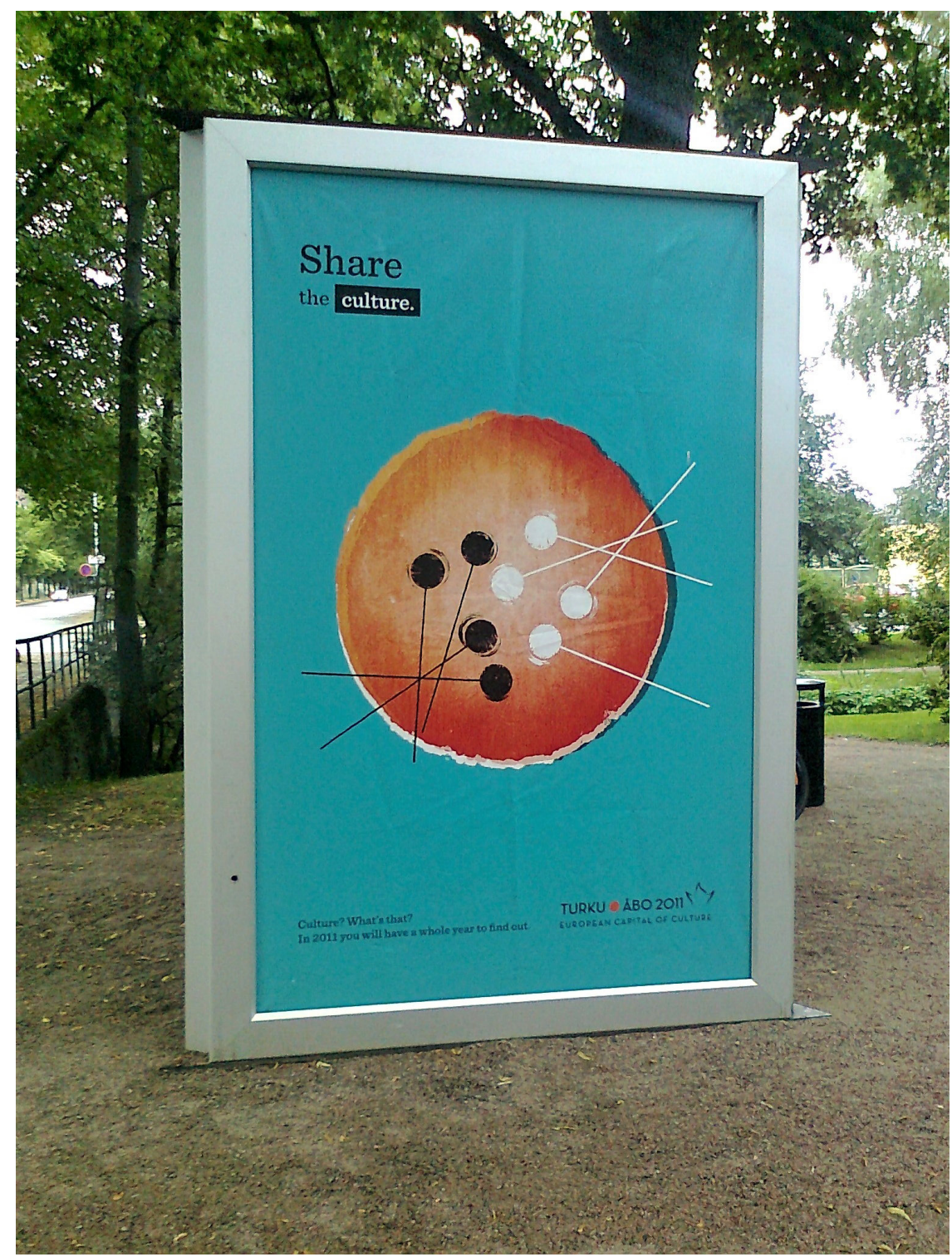

FIGURE 4.2 In Turku, the ECOC title was advertised in the city center through large sign boards that played with the logo of Turku2o11. PHOTO: TUULI LÄHDESMÄKI

promotional material that listed the countries of origin of the performers or artists also emphasized this multinationality (Figure 4.3). Some events in the case ECOCs focused particularly on celebrating folk cultures in Europe, such as folk dance or folk music. At these events, 'multinational Europe' could be perceived through different folk costumes, dances, and musical styles (Figure 4.4). 


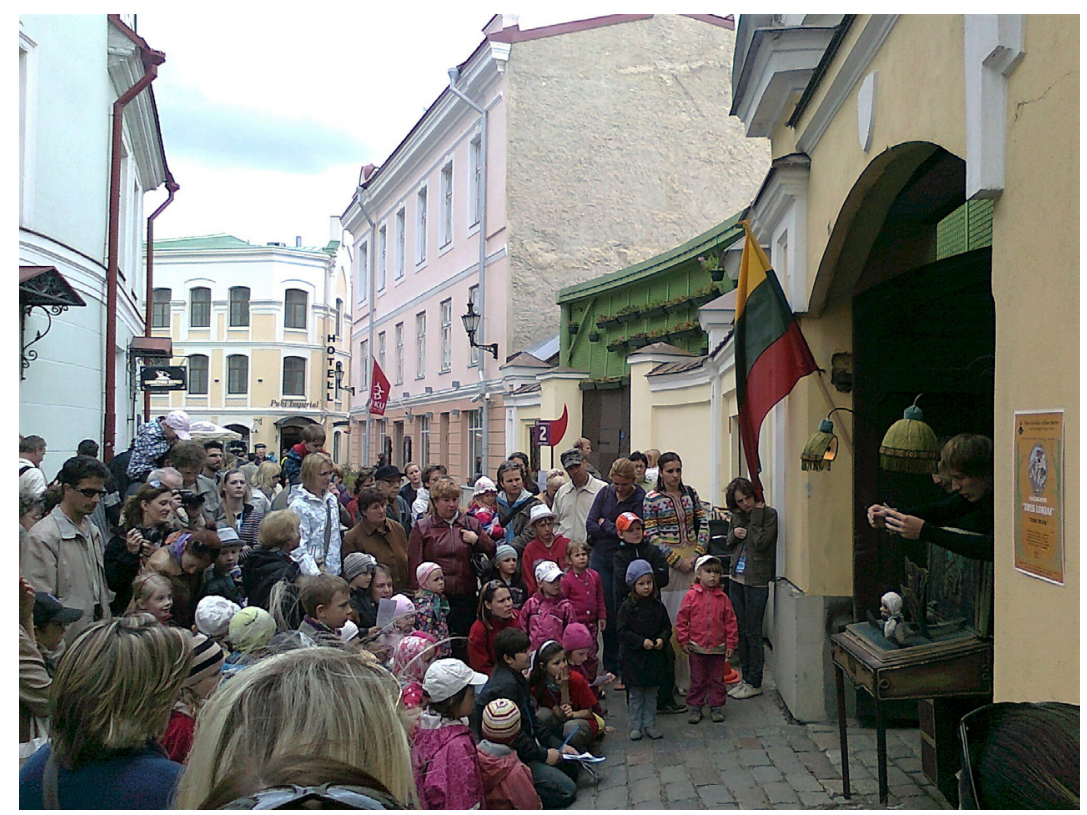

FIGURE 4.3 Outdoor performance by a Lithuanian group at the puppet theatre festival in Tallinn2011. The flag indicates the home country of the group. PHOTO: TUULI LÄHDESMÄKI

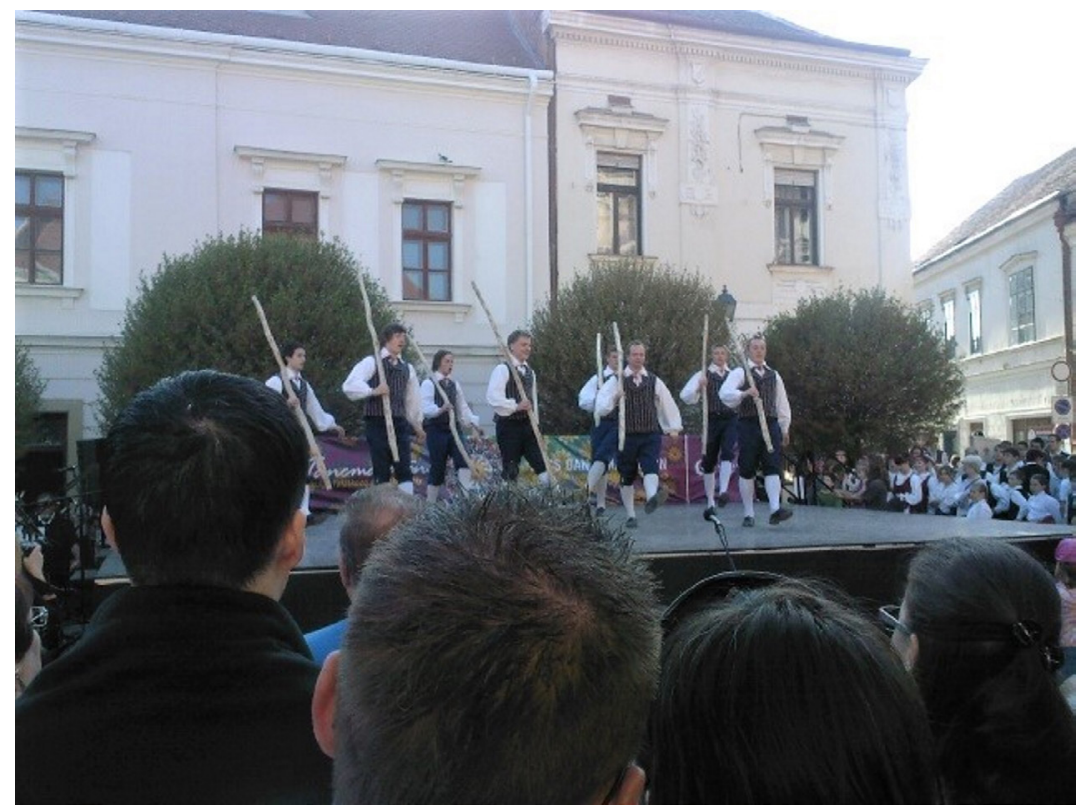

FIGURE 4.4 Finnish performers wearing folk costumes at the folk dance festival in Pécs2o1o. PHOTO: TUULI LÄHDESMÄKI 
Rather than folk traditions, the ECOC programmes more commonly focus on contemporary urban culture. Programme events seek to enliven cities through contemporary public art and community art projects, aiming at bringing people together and enabling them to participate in diverse creative activities. This kind of contemporary urban culture invokes associations with European metropoles from where the latest street art and 'cultural buzz' spread to other urban environments. In the case Ecocs, it was difficult to overlook the new artistic projects in urban space. These projects commonly included temporary public art in squares or parks (Figure 4.5) or smaller street art projects enlivening the urban space and its structures (Figure 4.6) in the city centers.

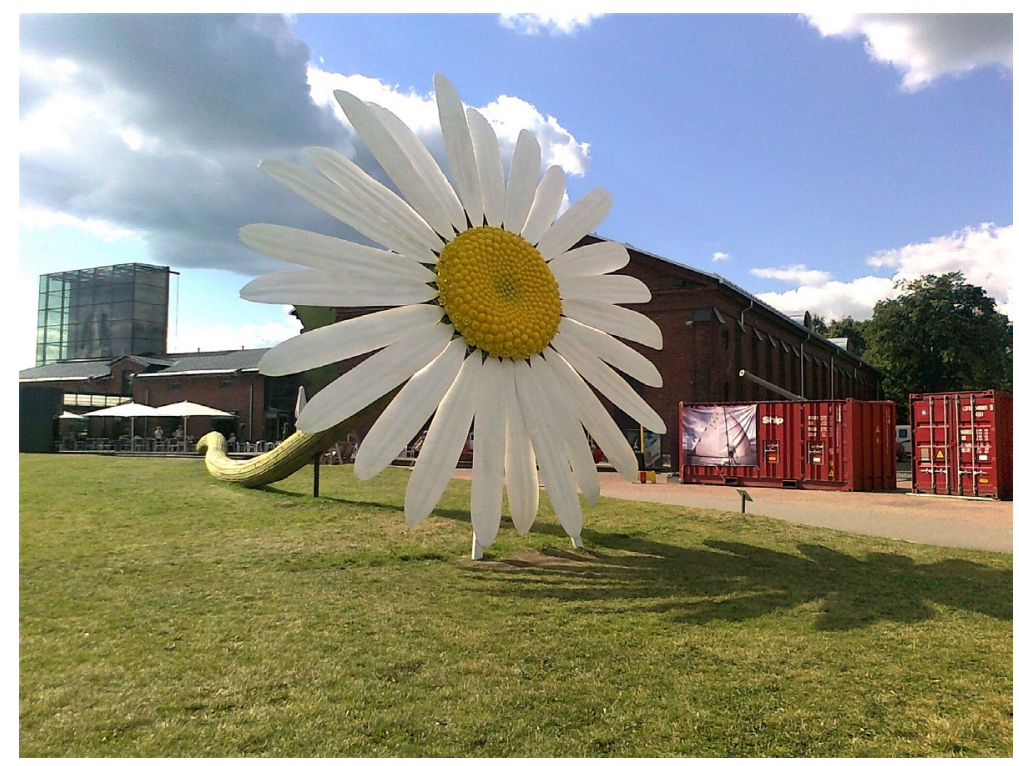

FIGURE 4.5 Daisy by Jani Rättyä and Antti Stöckell at the 'Flux Aura' environmental art festival in Turku2o11.

PHOTO: TUULI LÄHDESMÄKI

The ECOC year is usually combined with improving the respective city's (cultural) infrastructure. In many Ecocs, particularly in Central and Eastern Europe, the ECOC year has meant major regeneration plans, investments in diverse infrastructural projects, restoration of buildings and public spaces in city centers, and construction of new buildings for cultural uses (Lähdesmäki 2014b). In all the three case ECOCs, the city centers were transformed, polished, and enlivened in more or less permanent ways, and new cultural spaces were built to enrich the urban cultural scene. In Pécs (Figure 4.7), these changes were the most dramatic and could be perceived form the point 


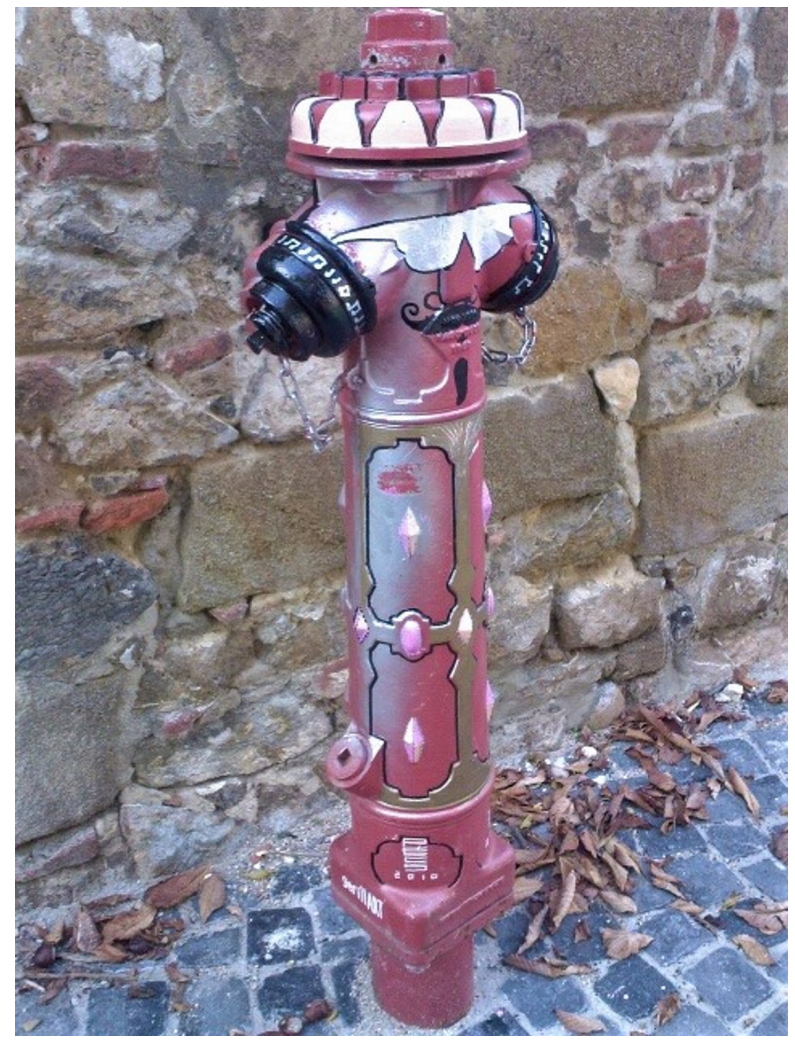

FIGURE 4.6 Painted water post with the Ecoc logo in Pécs2o1O. PHOTO: TUULI LÄHDESMÄKI

of view of the 'European'. The construction and renovation projects in the city were linked to Europe and the EU through signs indicating that the EU was a project funder. The renovations of buildings and public spaces in the center turned Pécs into a modern 'European city' like many others, with medieval and classical architectural layers and modern urban furniture. In general, the construction of (cultural) infrastructure, renovation of buildings, and transformation of urban spaces are probably the most influential components of the ECOC year. They not only change the city space but also impact on visitors' and inhabitants' notions of the city, as well as their movement, activities, and cultural behavior in the city.

The ECOC title has diverse influences on their host cities. Investing in cultural buildings, regenerating public spaces, hosting multinational cultural festivals, and implementing projects of contemporary urban culture create the ECOCs active, cultural atmosphere and groomed look. A researcher who has visited various ECOCs during the past decade can easily recognize similarities, 




FIGURE 4.7 Renovating and constructing Széchenyi square in Pécs during its Ecoc year. PHOTO: TUULI LÄHDESMÄKI

repetitions, and reminders of other ECOCs. All cities seem to come up with very similar ideas and seek to emphasize the same ideals in their promotion of the European dimension. Some of the photos taken during the fieldwork are therefore so similar that their locations are difficult to tell based on the image alone. This similarity can be perceived as stemming from the nature of the ECOC action based on a competition and a set of selection criteria (Lähdesmäki $2014 \mathrm{~b}$ ). All the candidates seek to fit their applications, plans, and programmes into this framework, as well as to find and utilize the most recent trends in participatory culture, cultural regeneration, and revitalization of urban space. As a result, the ECOC action has succeeded in constructing a year-long urban event that we find very 'European' in a sense that its European dimension is constantly discussed, negotiated, debated, manifested, and, thus, constructed in it.

\section{Construction of Europeanness among Ecoc Audiences}

\subsection{Researching Europeanness: Data and Methods}

Audiences of the ECOC events have diverse views on Europe and how it is eventually manifested in the events they experience. Next, we examine these views 
through a questionnaire issued during the fieldwork in Pécs, Tallinn, and Turku. The data comprises 1,425 responses: 200 from Pécs, 293 from Tallinn, and 400 from Turku collected through printed questionnaires, and $53^{2}$ responses to a pilot online survey from Pécs. During the field research, the questionnaire data was collected at 23 events in Pécs, 17 events in Tallinn, and 21 events in Turku. The selected events differed greatly in their size, location, organization, target audience, and genre. Some were festivals or series of events including various types of performances. The aim was to include in the study an extensive range of events, which would represent the variety of the whole ECOC programme in the case cities. The respondents (aged 15 and older) were selected during or after the chosen events. The data collection was based on focal sampling (Mony and Heimlich 2008; Yocco et al. 2009): In advance, the data collectors divided the event venue (public space or foyer) into three to five imaginary parts and aimed to collect one to ten responses from the people who happened to be in the middle of the imagined areas. From three to thirty responses were collected from each event depending on its size.

The online pilot study in Pécs was based on a combination of convenience, purposeful, and snowball sampling (Patton 2002; Everett and Barrett 2009): Notice of the online questionnaire was sent to the contact persons of ten local cultural organizations or networks representing various cultural fields. Contact persons were advised to inform their staff and stakeholders about the questionnaire. The responses were collected online from February till May 2010.

The printed questionnaire was available in Pécs in Hungarian and English, in Tallinn in Estonian, Russian, English, Finnish and Swedish, and in Turku in Finnish, Swedish, and English. Those languages that the fieldwork researcher was not able to read were translated to English by local research assistants with experience of doing translations. Core information of the respondents is gathered to the Annex 1.

The questionnaire included 23 questions with a focus on respondents' notions of the 'local', 'regional', 'national', and 'European' and how they felt these dimensions were and should be represented in the ECOC events. Here, we focus only on the 'European' and how it was constructed in the closed and open responses. A more detailed qualitative analysis of the responses from each case city and a comparison of the results on the four scalar dimensions in the three cities have been presented elsewhere (Lähdesmäki 2011; 2013a; 2013b; 2014a; 2014c; 2014d).

One aim of the questionnaire study was to explore the ECOC audiences' notions of the 'European' through the concept of Europeanness. The concept was not explained or defined in the questionnaire: Respondents were instructed to concretize and describe it according to their own understanding. However, the ECOC events through which they were recruited probably 
guided respondents to perceive the concept in cultural and social terms. In the analysis, we first focus on the responses to closed questions on the 'European'. After this, we focus on open questions and explore the respondents' notions through qualitative thematic analysis. Here, we look at two questions: 'In your opinion, how is Europeanness represented in the European Capital of Culture events?' and 'In your opinion, how should Europeanness be represented in the European Capital of Culture events?'

In the analysis, we sought to identify expressions of themes recognized from the responses through careful reading and constant comparison between linguistic patterns. For us, a theme could be expressed in "a single word, a phrase, a sentence, a paragraph or an entire document", as Zhang and Wildemuth $(2009,310)$ have described the premises of qualitative thematic analysis. Our aim was to structure the 'polyphonic' nature of the responses in order to perceive how the 'European' was constructed in data. First, we identified a broad variety of different topics and linguistic expressions in the responses, and then we arranged and combined similar recurring topics and expressions under unifying themes, as systematically as possible. The most frequent themes - which inevitably overlap - are shown in Table 4.3. After this, the identified themes were quantified in order to get an idea of their frequency. In the quantification, each identified theme was given a code number and the responses to the open questions were coded with these numbers. The thematic quantification of the responses was content-based, not respondent-based. Thus, a response from one respondent might comprise several views of the 'European'.

\subsection{Quantifying Respondents'Views of Europeanness}

The analysis of the closed responses indicates that the EU's identity political aims for the ECOC action were fulfilled from the point of view of the ECOC audiences. Most of the respondents had very positive views of Europeanness and thought that it was and should be represented in the ECOC events. Of all respondents, $49 \%$ saw Europeanness as to some extent important and for $42 \%$ it meant a lot for their identity; $74 \%$ considered that for them, Europeanness invoked positive or very positive impressions; $62 \%$ thought that it was and $71 \%$ that it should be represented a lot or very much in the ECOC events. When comparing these figures for the case Ecocs, the respondents from Tallinn seemed to have the most positive attitude to Europeanness overall, while respondents from Turku emphasized it less (Table 4.1).

Despite these positive views, in all the case Ecocs, 'national culture' invoked even more positive impressions in the respondents and it was considered as the dimension that the ECOC events should represent the most. The open questions revealed, however, that views on Europeanness and national culture were nuanced and included some controversial meanings. 
TABLE 4.1 Views of Europeanness among the respondents of the ECOC questionnaire study

\begin{tabular}{|c|c|c|c|c|}
\hline & $\begin{array}{l}\text { Respondents } \\
\text { considering } \\
\text { that } \\
\text { Europeanness } \\
\text { means 'a lot' for } \\
\text { their identity }\end{array}$ & $\begin{array}{l}\text { Respondents } \\
\text { in whom } \\
\text { Europeanness } \\
\text { invokes 'positive' } \\
\text { or 'very positive' } \\
\text { impressions }\end{array}$ & $\begin{array}{l}\text { Respondents } \\
\text { for whom Ecoc } \\
\text { events represent } \\
\text { Europeanness } \\
\text { 'a lot' or 'very } \\
\text { much' }\end{array}$ & $\begin{array}{l}\text { Respondents } \\
\text { for whom ECOC } \\
\text { events should } \\
\text { represent } \\
\text { Europeanness 'a } \\
\text { lot' or 'very much' }\end{array}$ \\
\hline Pécs, paper & $44 \%$ & $64 \%$ & $66 \%$ & $73 \%$ \\
\hline Pécs, online & $45 \%$ & $72 \%$ & $6 \circ \%$ & $77 \%$ \\
\hline Tallinn & $46 \%$ & $8 \circ \%$ & $67 \%$ & $76 \%$ \\
\hline Turku & $33 \%$ & $77 \%$ & $55 \%$ & $59 \%$ \\
\hline
\end{tabular}

In general, the results of the questionnaire study indicate that different scalar dimensions of culture - 'local', 'regional', 'national', and 'European' - are important and meaningful to the respondents, and international cultural events, such as the ECOC, are expected to represent scalar dimensions of culture both directly in their contents and indirectly in their organization and promotion. People structure their cultural perceptions and notions on cultural differences around these scalar dimensions.

In the policy discourse, the Ecoc's key scalar focus is on Europe. Sassatelli (2009, 129-131) investigated the ECOC action's European dimension by interviewing key informants, such as programme directors, project managers, artists, curators, and local stakeholders, in nine Ecocs for the year 2000. The majority of her interviewees responded positively to the questions about the existence of European culture and identity: The idea that Europe should be the focus of the ECOC initiative and its implementation was never challenged (Sassatelli 2009, 135). Sassatelli notes, however, that the interviewees seemed to have difficulties verbalizing the idea of European culture or identity in a way that satisfied them. How did the ECOC audiences in Pécs, Tallinn, and Turku verbalize Europeanness? The open responses in the questionnaire study illustrate diverse ways of perceiving it and understanding its essence (Table 4.2).

\subsection{Europeanness in Respondents' Words}

The respondents in all the case cities most often approached Europeanness in the ECOC events by emphasizing the involvement of Europeans in them, such as European (or just foreign) artists and performers, European visitors to 


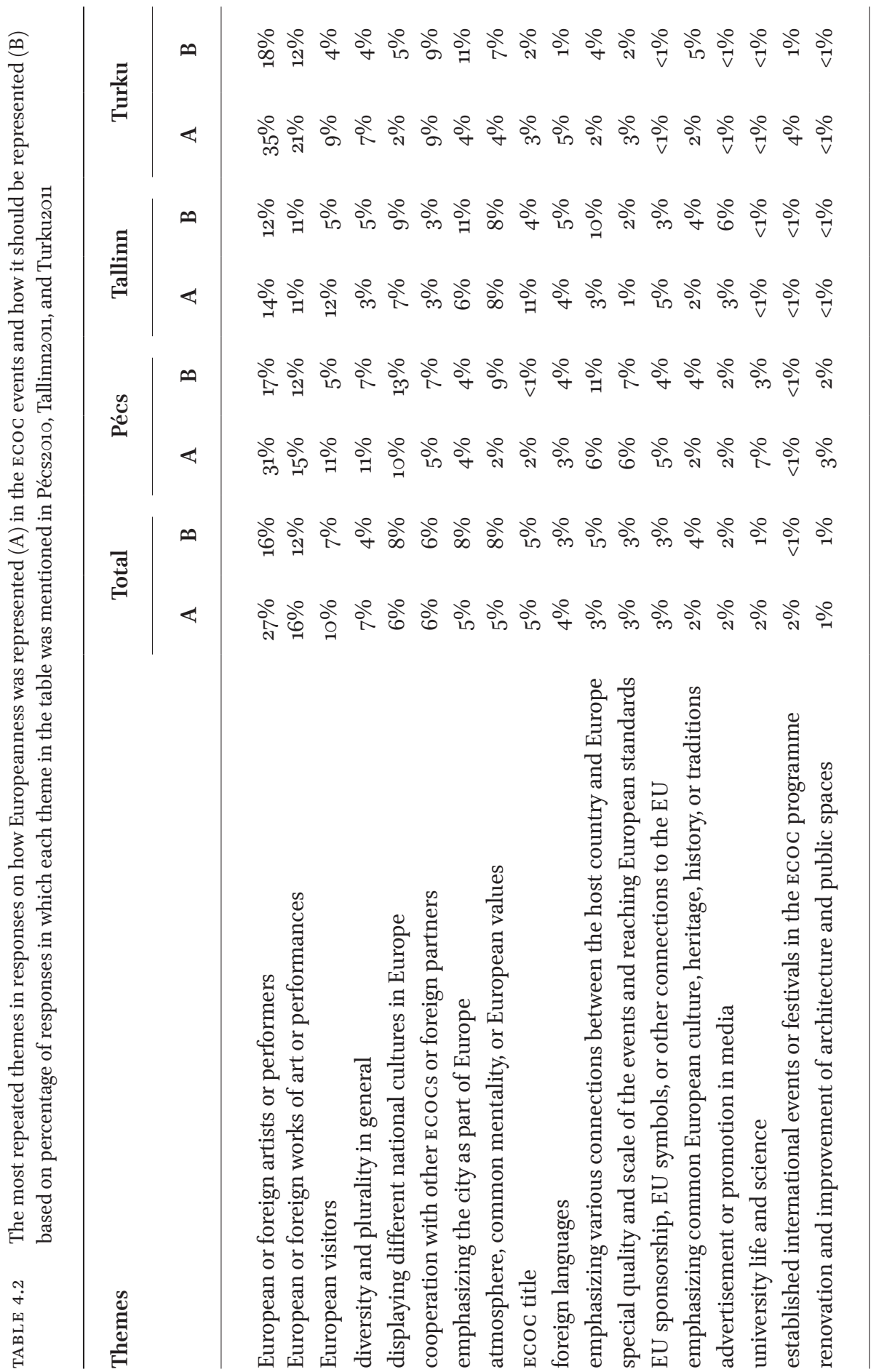


the cities, and European partners in diverse cooperation projects during the ECOC year. In these responses, Europeanness was verbalized as being manifested for example in "joint projects that cross state borders" (Turku, male, b. 1950), "cooperation with other European countries" (Turku, female, b. 1971), or "involving European friend and partner cities to the events" (Pécs, male, b. 1980). The respondents commonly mentioned the presence of people who were considered as 'Europeanizing' the ECOC events. These "European personalities" (Pécs, male, b. 1985) were seen as having an influence on the 'European' atmosphere of the city as "the artists from abroad bring a piece of Europe to us" (Pécs, male, b. 1982). Besides European or foreign performers, the respondents commonly stressed foreign visitors and tourists as indicators of Europeanness. They noted for instance: "I see and hear a lot of foreign people" (Pécs, female, b. 1965), "in the events, you can see and hear a plenty of different nationalities" (Turku, male, b. 1982), and "hundreds of tourists in the squares of the city: it is Europe to me" (Tallinn, female, b. 1935). In addition, the visitors from abroad could be seen as Europeanizing the Ecocs and their host countries through being informed by the cities' and countries' 'European essence', as one respondent (female, b. 1989) described Europeanness in Tallinn:

First of all, it is represented in the form of the visitors to the Estonian state. I am sure that many people will notice that, after all, Estonia is not an unknown and a far-away country in Russia, but a beautiful and modern country in Europe.

Besides artists and performers, the respondents also commonly emphasized the exhibitions of European (or foreign) art and cultural performances from abroad as indicators of Europeanness in the ECOC events. For most of these respondents, the contents or topics of the exhibitions, performances, or artistic projects, were not crucial - the home country of their artists, performers, or producers was more significant in perceiving the event as a representation of Europeanness. Thus, notions of Europeanness were closely linked in the data to the distinction between the 'national' and 'non-national': other nationalities manifested Europe and Europeanness. The nationality of artists and performers from another European country determined the European character of the events. These notions also indicate how mobility is perceived as fundamental to the idea of Europe. Moving artists, the arts, and people as visitors, audiences, and tourists characterize respondents' notions of Europe.

Reflecting clear categories of the 'national' and the 'foreign', many of the respondents connected Europeanness to the display of different national cultures in the ECOC events. This notion of Europeanness emphasizes the uniqueness 
and particularity of national cultures - and Europeanness as being composed of them and their differences rather than having a shared culture, heritage, or identity of its own. In these responses, Europeanness could be manifested through "thematic programmes on European countries" (Pécs, female, b. 1965), events in which "each national culture is represented" (Tallinn, female, b. 1992), and "[d]ifferent performances of European artists groups, who present the cultural traditions of just their own country" (Turku, female, b. 1951). As another respondent from Turku noted: "It would be fun to see more differences between different countries" (Turku, female, b. 1957). These responses indicate how Europe was often perceived as a 'Europe of nations'.

Europeanness was also quite often related to more general cultural diversity in the case cities, different languages heard and used in the ECOC events, and various other modes of cultural and social plurality. Thus, Europeanness could be explained as being manifested in "multilingual events" (Pécs, female, b. 1977), displaying "the culture of European minorities" (Pécs, female, b. 1988), and "giving an opportunity to ethnicities and minorities to perform" (Pécs, female, b. 1987). Many of respondents equated Europeanness simply with diversity. As one respondent from Tallinn stated: "What do we now think that goes under Europeanness? Diversification, everything that is not mainstream? If so, then it is shown" (Tallinn, male, b. 1987). In contrast, a few respondents in Tallinn criticized the ECOC discourse for presenting the city more culturally diverse than it was considered to be. As one respondent noted: "Tallinn and to [a] lesser extent Estonia is tried to be shown as [more] European and multicultural and urban than it is in reality" (Tallinn, female, b. 1986).

The emphasis on the 'European' in the EU policy rhetoric, and hence in the Ecocs' promotional discourse, impacts inevitably on the reception of the ECOC events. In their open responses to the questionnaire, many respondents repeated the slogans and expressions used in the official promotional material of the case ECOCs. In general, the ECOC action was often considered European or typical of Europe: "The Cultural Capital initiative is already itself very European. At least, I have never heard anything like it from the United States or Asia, etc." (Turku, male, b. 1988). In Pécs and Tallinn, the ECOc links to the $\mathrm{EU}$ - such as the EU funding of the certain events and regeneration projects in the city and the presence of the EU flag in ECOC events and promotional material - were considered as indications of Europeanness. In many responses from these cities, the notions of Europeanness were intertwined with the EU, as these two respondents from Pécs noted: "The whole city is full of plaques about [the EU] support. In addition, every time (for example in the welcoming speeches) the question of Europeanness is addressed" (Pécs, female, b. 1965); "We are an EU member state, Pécs is the European Capital of Culture in 2010: 
an integral part of the EU, and this is stressed in the events" (Pécs, female, b. 1987). Various links with the EU, as well as the ECOC title itself, could be seen as Europeanizing the host city, as one respondent (female, b. 1990) from Tallinn noted:

Europe is already inside the title. Also because it is a question of the European Capital of Culture, we are now in a way totally taken as Europeans, which we have been afraid of. Afraid that we are not Europeans or that we are not taken as Europeans.

This quotation also reflects the respondent's view on Tallinn's and Estonia's liminal position in becoming European. In general, it was expected that Europeanness would be represented in the ECOC events as a rather 'thin' cultural identity (on thin and thick identities, see Delanty 2003; Axford 2006; Davidson 2008; Terlouw 2012): that is, an identity transmitted and represented through contemporary international cultural actors and their interaction and presence in the Ecocs and realized through the (sometimes forgotten or ignored) 'fact' that the ECOCs and their host countries are already part of Europe. This fact was often seen as proved by the EU membership of these countries or their other links to the EU. Respondents rarely discussed Europeanness as a 'thick' cultural identity based on common European culture, history, heritage, traditions, monuments, or historical sites. In Pécs, these latter views were often linked to major restorations and renovations of historical buildings, monuments, and squares in the city center. The Europeanness of the city was linked to its improved appearance. As one respondent from Pécs explained, the Europeanness was manifested "[a]bsolutely in the appearance of the renovated squares and the reconstructed buildings. In attempts to develop up to the standards of other European cities" (Pécs, female, b. 1989).

In general, the notions of Europeanness in the data were notably nonhistorical. The lack of history in the responses on Europeanness can be interpreted in several ways. First, Europeanness may be commonly perceived through contemporariness - as a cultural identity shaped through relations and interaction between people in the present time. Second, Europeanness may be easily associated with the EU, particularly in the context of EU cultural initiatives. Third, history is often related to identity formation at the national or local not the European - level (see Mayer and Palmowski 2004). History and cultural traditions were indeed more often discussed in the questionnaire responses related to local, regional, and national culture. Fourth, the ECOC action celebrates contemporary culture, 'living' traditions, and intangible heritage, which does not guide the audiences to perceive Europe in historical terms. 
While respondents typically related tangible culture to the 'local' or 'national', many of them characterized the 'European' by a particular atmosphere or mentality, emphasizing its intangible character. In all case cities, this atmosphere or mentality was described mostly in positive terms, such as being tolerant, open-minded, modern, civilized, and united. Thus, Europeanness was understood as a set of certain liberal values. These values included being cultural and civilized" (Turku, female, b. 1963), "inclusion of young people [and] elderly people (> very European!)" (Turku, female, b. 1982), "ability to act together" (Turku, male, b. 1945), "patience and paying attention" (Pécs, female, b. 1981), "tolerance, diversity, hospitality" (Tallinn, male, b. 1974), "positive thinking, inclusiveness, hospitality, solidarity, tolerance and openness" (Pécs, female, b. 1984), and "peaceful, helpful, and smiling mentality, which characterizes an established peaceful democracy and the well-being in Europe" (Pécs, female, b. 1965). Moreover, some of the respondents related the 'European' in the ECOC events to their manifoldness, experimentality, innovativeness, and "high standard, quality and professional arrangement" (Pécs, female, b. 1988). If the events were considered as lacking this expected quality, appealing to Europeanness could be used to argue for this. As one respondent from Turku stated: "Unfortunately the level of communication / organization [of the ECOC events] do not reach the common European standards" (Turku, male, b. 1978).

Besides liberal values and high quality, some respondents linked the intangible nature of Europeanness to the 'modern' in all case ECOCs, and, particularly in Pécs and Tallinn, to the idea of development. This idea meant the improvement and modernization of urban spaces in the city, developing better living standards, and a well-functioning and fair society. Responses on Europeanness mentioned for example, the "economy and development" (Pécs, female, b. 1986), "working conditions" (Pécs, female, b. 1990), and "reaching the standard of the European Union" (Pécs, male, b. 1987). The idea of the 'European' being sought after and needing to be 'reached' was included in several responses. As a respondent from Tallinn put it: "We want to be like other Europeans. That means that everything is fine and in good order and good condition" (Tallinn, male, b. 1955).

\subsection{The Relationship between the 'National' and the 'European'}

In the all case Ecocs, 'national culture' and 'Europeanness' formed a conceptual pair that could be considered as closely connected, even inseparable dimensions of culture and identity, but at the same time as contradictory elements. Indeed, 'national culture' was discussed in many of the responses as involving a positive patriotic ethos and, thus, crucial to strengthening the national feeling of belonging and maintaining national cultural particularity. 
Some respondents, who strongly emphasized the importance of 'national culture' in the ECOC events, interpreted Europeanness as its rival opposite. In such accounts, Europe was often closely linked to the EU. As one respondent noted: "It [Europeanness] should be less important than our own identity. We should not belong there [the EU] at all, it [the ECOC year in Pécs] should be about what we are" (Pécs, male, b. 1986). In some responses (e.g. Pécs, female, b. 1989), Europeanness was considered as a direct threat to a more important national identity:

Primarily, the interests of the city and the country should be kept in mind, and after that those of Europe. The lowest level of Europeanness should be addressed, even if we are members of the EU. We should be members of the Union in a way that we would still preserve our identity, and not merge with everyone.

In these views, Europeanness was interpreted as a homogenizing identity, which flattens the particularity and originality of national cultures in Europe. Thus the ECOC action with its emphasis on including the European dimension in events raised concerns. As one respondent noted regarding Tallinn's ECOC programme, "Europe must not prevent Estonia from keeping its culture" (Tallinn, female, b. 1988). The threat of the 'European' included negative views on the unwanted blurring of (national) cultural characteristics and originality of cultural phenomena. As one respondent from Turku stated: "The Capital of Culture should emphasize the culture of the particular country instead of the European muddle" (Turku, male, 1981).

In the responses emphasizing the importance of national culture, the 'national' and 'local' were commonly perceived as easily recognizable, clear, and coherent entities, while Europeanness was interpreted as being more diverse and incoherent, and thus blurred in a negative way. In these views, the idea of multi-layered cultural identities did not reach the supranational level. The local and national culture were often perceived as linked and their representations could be described as enmeshed, but the distinction between them and Europeanness remained clear - probably because conceiving of Europeanness was difficult.

Moreover, some respondents from all three cities approached Europeanness, again tightly entwined with the $\mathrm{EU}$, as a bureaucratic force to which 'national cultures' have to stand up. The rise of nationalist, populist, and radical rightwing movements in all three case countries may have encouraged some respondents to stress the European dimension as a negative counter-discourse to the 'national'. During the data collection, debates on nationalism were particularly 
timely in Hungary due to the parliamentary election in the spring of 2010. The election was preceded by active political campaigns in which right-wing parties with their conservative and nationalistic rhetoric received strong media attention. The tension caused by the election and the victory of the right-wing parties was also reflected in the reception of the ECOC events in Pécs: Partypolitical points of view and nationalist rhetoric were present in several responses (Lähdesmäki 2011). As one respondent stated: "Instead of the Union, present true Europeanness: Christian and Aryan traditions" (Pécs, male, b. 1984). The debates on nationalism are still very timely in Hungary, as indicated for instance by the parliamentary election in 2019. In it, national and Christian traditions were juxtaposed with internationalization (that was connected with anti-Semitism), the EU, and its interest in deeper political integration.

In pro-European responses, 'national culture' could be considered as including certain negative values and qualities, such as a narrow-minded national ethos, which many of these respondents wanted to overturn. Among these respondents, Europeanness was seen as a positive element that could renew the content of 'national culture' (Lähdesmäki 2013b; 2014a). In the responses that were positive about Europeanness, it was often contrasted with recent history and its impacts on the societal and political climate in the case countries. Particularly in Pécs and Tallinn, respondents often discussed being part of Europe and its economic, social, and cultural sphere in relation to societal changes in these countries.

After the collapse of the socialist regimes, Eastern and Central European countries commonly emphasized their cultural and historical links to Europe, their Europeanness, as the countries aimed to detach themselves from their socialist identities and image (Kolankiewicz 1993, 106-107). A similar discourse was used when Hungary and Estonia joined the EU in 2004 and when Estonia joined the Eurozone in 2011. These strengthened connections to the European polity, increased public debate on European issues, and positive expectations regarding the EU and Eurozone memberships might influence the respondents' positive views of Europeanness in Pécs and Tallinn. As discussed above, many respondents described Europeanness in relation to the EU with pride, feeling the importance of being part of the Union. In Tallinn, the Euro currency was presented in a positive light in several instances where respondents shared their views of Europeanness.

While many respondents contrasted the 'national' and the 'European', plenty of others stated that national culture and identity were important elements of Europeanness. In these instances, the notion of Europeanness was often seen as multi-layered: People have multiple identities, which are mobilized in particular circumstances. The same qualities and issues serve as markers of various 
identities in different situations or discourses (Lähdesmäki 2014a). Thus, many of the respondents emphasized - in their words - the "natural", "self-evident", and "taken-for-granted" links between the city, region, country, and Europe or the EU. To take one case from each city: "Culture of Pécs = Hungarian culture = A part of European culture" (Pécs, female, b. 1949), "Turku has always been a part of Europe, thus Europeanness is a natural part of Turku. Turku is the most European and international city in Finland" (Turku, female, b. 1969), and "I do not know how to separate the concepts of what is Europeanness and Estonianness. For me, Europeanness is a part of Estonia" (Tallinn, female, b. 1977).

The analysis of the questionnaire data from Pécs2010, Tallinn2o11, and Turku2011 reveals how the audiences of the ECOC events constructed the 'European' through what Billig (1995) calls "banal" forms of culture. These forms included well-known and repeated symbols of the EU, such as the EU flag, and easily recognized features of diversity and difference, such as people speaking and performing in foreign languages. The notions of the 'European' were commonly drawn from the respondents' everyday experiences of encountering 'European people' - artists, performers, and visitors from other European countries - and enjoying cultural events known to have been produced by or in cooperation with artists, performers, or cultural producers from other European countries. The 'European' in the responses mainly appeared in everyday life and a familiar environment. Besides in the events, the respondents encountered the 'European' in the atmosphere of the cities as well as, in Pécs, in the renovated, developed, and improved urban spaces in the city center.

Respondents commonly constructed the 'European' through their own participation in (European) culture. This participation ranged from enjoying (European) cultural events in the audience to communicating and cooperating in various ways with 'European people' during the ECOC year. It included physical movement in the urban space, engagement with the 'beat of the city', and sensing its atmosphere, transformation, and cultural peculiarities. This kind of experience of 'lived space' in the Ecocs, in Lefebvre's (1991) terms, produced 'lived' experiences of Europeanness (Lähdesmäki 2014e).

Such everyday experiences of the 'European' are likely to invoke everyday experiences of belonging to Europe. One EU aim for the ECOC action is to 
"increase citizens' sense of belonging to a common cultural area" (EC 2014, 4), as discussed Chapter 3. The EU officials have been concerned about how this EU politics of belonging is being implemented in the ECOC programmes: in their understanding, a strong European dimension is lacking. The analysis of the questionnaire responses from Pécs2010, Tallinn2o11, and Turku2o11 indicate the cities' cultural events did evoke a sense of the 'European', though this was less linked to the contents of the events or shared European culture or common heritage or history. The analysis reveals how many respondents experienced Europe and the 'European' through contemporary cultural practices in everyday environments and how the EU has become an internalized everyday actor in people's lives.

The analysis also shows how the respondents approached the different layers or dimensions of culture and cultural identity through relationships - either in terms of connectedness or distinctiveness. On the one hand, the respondents emphasized culture as multi-layered and cultural identities as 'thin' categories, which are intertwined and entangled in various ways. On the other hand, the respondents perceived cultural identities, especially local and national culture, as 'thick' and essentialist categories that were clearly distinguished and should not be meshed with the 'European'. The previous analysis of the data has revealed some differences in respondents' views of the multi-layered nature of culture and cultural identities in different case cities (Lähdesmäki 2013b). In Pécs, more respondents strongly emphasized distinction than integration of different scalar layers of culture, while in Turku the idea of integrating these layers was strongest. In Tallinn, the views on these scalar layers were more evenly balanced, however, integration was raised slightly more often than distinction.

The exploration of macro-, meso- and micro-level discourses within it reveals how the politics of belonging functions in the ECOC action. The macrolevel policy aim of strengthening Europeans' feeling of belonging to Europe and the EU dovetails with the meso-level policy and promotional discourses and guides the implementation of ECOC cultural programmes. This macrolevel politics of belonging is also diffused to the micro-level and is reflected in the views and notions of people who participate in ECOC events. However, this process is not only in one direction: Participants play a proactive role in the EU cultural initiatives. Like our other two case studies, our ECOC case study indicates that belonging to Europe and the EU is also initiated and constructed at the micro level and in 'lived space' through which people experience, grasp, and give meanings to Europe. 


\section{References}

Axford, B. 2006. "The Dialectic of Borders and Networks in Europe: Reviewing 'Topological Presuppositions'” Comparative European Politics 4 (2): 16o-182.

EC (European Commission). 2014. "Decision No 445/2014/EU of the European Parliament and of the Council of 16 April 2014 establishing a Union action for the European Capitals of Culture for the years 2020 to 2033 and repealing Decision No 1622/2006/EC." Official Journal of the European Union L 132: 1-12.

Ecorys 2011. Ex-post evaluation of 2010 European Capitals of Culture. Final Report for the European Commission DG Education and Culture. Birmingham: Ecorys.

Ecorys 2012. Ex-post Evaluation of 2011 European Capitals of Culture. Final Report for the European Commission DG Education and Culture. Birmingham: Ecorys.

Everett, M., and M. S. Barrett. 20o9. "Investigating Sustained Visitor/Museum Relationships: Employing Narrative Research in the Field of Museum." Visitor Studies 12 (1): 2-15.

Davidson, A. C. 2008. “Through Thick and Thin: 'European Identification' for a Justified and Legitimate European Union." Journal of Contemporary European Research 4 (1): $32-47$.

Delanty, G. 2003. "Is There a European Identity?" Global Dialogue 5 (3-4). Accessed 13 March 2020. http://www.worlddialogue.org/content.php?id=269

Helander, N., S. Innilä, M. Jokinen, and J. Talve, eds. 20o6. Turku on Fire. The Application of the City of Turku for the European Capital of Culture 2011. Turku: City of Turku.

Kaasik-Krogerus, S. 2019. "Politics of Mobility and Stability in Authorizing European Heritage: Estonia's Great Guild Hall." In Dissonant Heritages and Memories in Contemporary Europe, edited by T. Lähdesmäki, L. Passerini, S. Kaasik-Krogerus, and I. van Huis, 157-181. NewYork: Palgrave Macmillan.

Kolankiewicz, G. 1993. "The Other Europe: Different Roads to Modernity in Eastern and Central Europe." In European Identity and the Search for Legitimacy, edited by S. García, 106-13o. London: Pinter.

Lähdesmäki, T. 2011. "Contested Identity Politics: Analysis of the EU Policy Objectives and the Local Reception of the European Capital of Culture Programme." Baltic Journal of European Studies 1 (2): 134-166.

Lähdesmäki, T. 2013a. "Interpretations of Cultural Identities in the European Capital of Culture Events in Turku." Ethnologia Fennica 40: 66-88.

Lähdesmäki, T. 2013b. "Identity Politics of the European Capital of Culture Initiative and the Audience Reception of Cultural Events Compared." The Nordic Journal of Cultural Policy 16 (2): 340-365.

Lähdesmäki, T. 2014a. Identity Politics in the European Capital of Culture Initiative. Joensuu: University of Eastern Finland. 
Lähdesmäki, T. 2014b. "European Capital of Culture Designation as an Initiator of Urban Transformation in the Post-socialist Countries." European Planning Studies $22(3): 481-497$.

Lähdesmäki, T. 2014c. "The Influence of Cultural Competence on the Interpretations of Territorial Identities in the European Capitals of Culture." Baltic Journal of European Studies 4 (1): 69-96.

Lähdesmäki, T. 2014d. "Area-based Identities and Their Audience Reception in the European Capital of Culture Events in Tallinn2o11." In Culture! Capital. Change? Effects of the European Capital of Culture Year on Tallinn's Cultural Life, edited by M. Hellrand, 109-131.Tallinn: Tallinn Creative Hub.

Lähdesmäki, T. 2014e. "Discourses of Europeanness in the Reception of the European Capital of Culture Events: The Case of Pécs 2010." European Urban and Regional Studies 21 (2): 191-205.

Lähdesmäki, T., V. L. A. Čeginskas, S. Kaasik-Krogerus, K. Mäkinen, and J. Turunen. 2020. Creating and Governing Cultural Heritage in the European Union: The European Heritage Label. London: Routledge.

Lefebvre, H. 1991. The Production of Space. Oxford: Blackwell.

Määttänen, S. ed. 2010. Aivan kuten epäilinkin: kulttuuria! Turku Euroopan kulttuuripääkaupunki 2011. Ohjelmakirja [As I Expected: Culture! Turku - the European Capital of Culture. Programme Book]. Turku: Turku 2011 Foundation.

Mayer, F. C., and J. Palmowski. 2004. "European Identities and the EU - The Ties That Bind the People of Europe." Journal of Common Market Studies 42 (3):573-598.

Mony, P. R. S., and J. E. Heimlich. 2008. "Talking to Visitors about Conservation: Exploring Message Communication Through Docent-Visitor Interactions at Zoos. Visitor Studies 11 (2): 151-162.

Patton, M. Q. 2002. Qualitative Research and Evaluation Methods. Thousand Oaks, CA: Sage.

Sassatelli, M. 2009. Becoming Europeans. Cultural Identity and Cultural Policies. New York: Palgrave Macmillan.

Takáts, J. 2005. Borderless City. European Capital of Culture - Pécs, 2010. Pécs: Pécs2010 Application Centre.

Tarand, K. 2006. Everlasting Fairytale, Tallinn... Tallinn: Foundation for Tallinn as the Capital of Culture.

Terlouw, K. 2012. "From Thick to Thin Regional Identities?" GeoJournal 77 (5): 707-721.

Toller, L. 2005. "Foreword." In Borderless City. European Capital of Culture - Pécs, 2010, by J. Takáts, 7. Pécs: Pécs 2010 Application Centre.

Yocco, V. S., J. E. Heimlich, E. Meyer, and P. Edwards. 20og. "Measuring Public Value: An Instrument and an Art Museum Case Study." Visitor Studies 12 (2): 153-163. 